\title{
In Vitro Anti-Wrinkle and Tyrosinase Inhibitory Activities of Grapefruit Peel and Strawberry Extracts
}

\author{
Endang Lukitaningsih*, Syamsu Nur, Fadilah Qonithah, Andi Zulbayu, Rina Kuswahyuning, \\ Rumiyati \\ Faculty of Pharmacy, Universitas Gadjah Mada, Yogyakarta, Indonesia
}

\begin{abstract}
The research aims to analyse the antioxidant, anti-tyrosinase and anti-wrinkle activities from grapefruit (Citrus Maxima L) and strawberry extracts. Samples were extracted by maceration using $96 \%$ ethanol and ethyl acetate, subsequently. The Ferric Reducing Antioxidant Power (FRAP) and $\beta$-carotene bleaching (BCB) were used to measure the antioxidant activity. The effect of anti-wrinkle was determined by testing the inhibition of elastase and collagenase enzyme, while anti-tyrosinase activity was analysed using mushroom tyrosinase enzyme. The results showed that strawberry extracts in ethanolic (SE) and ethyl acetate (SEA) have antioxidant activity in FRAP $\left(\mathrm{EC}_{50}=404.39 \pm 3.27 \mu \mathrm{g} / \mathrm{mL}\right.$ and $1978.65 \pm 37.25$ $\mu \mathrm{g} / \mathrm{mL}$ ) and $\mathrm{BCB}\left(\mathrm{IC}_{50}=292.30 \pm 4.69 \mu \mathrm{g} / \mathrm{mL}\right.$ and $671.11 \pm 6.74 \mu \mathrm{g} / \mathrm{mL}$ ). Whereas the grapefruit peel extracts both in ethanolic (GPE) and ethyl acetate (GPEA) have antioxidant activity in FRAP (EC $50219.47 \pm$ $71.96 \mu \mathrm{g} / \mathrm{ml}$ and $309.44 \pm 95.76 \mu \mathrm{g} / \mathrm{ml}$ ) and BCB (EC50 $245.19 \pm 162.47 \mu \mathrm{g} / \mathrm{ml}$ and $567.54 \pm 95.31 \mu \mathrm{g} / \mathrm{ml})$. As positive standards for FRAP antioxidant analysis were quercetin and vitamin $\mathrm{C}$ which has IC 50 respectively $18.97 \pm 4.50 \mu \mathrm{g} / \mathrm{mL}$ and $24.47 \pm 1.44 \mu \mathrm{g} / \mathrm{mL}$. While in BCB analysis, Butylated Hydroxy Toluene (BHT) used as positive standard ( $\mathrm{IC}_{50} 38.68 \pm 5.70 \mu \mathrm{g} / \mathrm{mL}$ ). The samples of SE, SEA, GPE and GPEA showed tyrosinase inhibitory activity which the $\mathrm{IC}_{50}$ values were respectively $492.68 \pm 1.43 ; 2658 \pm 48.08 ; 3312.5$ $\pm 222.74 ; 2985.17 \pm 122.80 \mu \mathrm{g} / \mathrm{ml}$. Kojic acid (IC50 $111.52 \pm 0.42 \mu \mathrm{g} / \mathrm{ml}$ ) is used as positive standard in this study. In addition, SE, SEA, GPE and GPEA were able to inhibit elastase and collagenase enzymes, although their activities were still lower than the positive standard used in this study. Elastastinal in concentration $50 \mu \mathrm{g} / \mathrm{mL}$ giving elastase inhibition about $71.71 \pm 0.81 \mu \mathrm{g} / \mathrm{mL}$, while vitamin $\mathrm{C}$ in the same concentration showed collagenase inhibition about $66.79 \pm 1.23 \mu \mathrm{g} / \mathrm{mL}$. It can be concluded that the extract of strawberry and grapefruit peel has antioxidant, anti-tyrosinase and anti-wrinkle activity through inhibition of elastase and collagenase enzymes; thus, they can be used as antiaging cosmetic ingredients.
\end{abstract}

Keywords: Citrus maxima L; strawberry; antioxidant; anti-wrinkle; anti-tyrosinase

\section{INTRODUCTION}

Skin aging, induced by intrinsic and extrinsic factors (photo aging), causes a loss of structural integrity and decreased skin function (Lephart, 2018). The main contributor to the two ageing processes is oxidative stress which damages the cells and the extracellular matrix of the skin (Giampieri et al., 2014; Karim et al., 2014). Oxidative stress occurs due to an imbalance between the production of reactive oxygen species (ROS) and antioxidants in the body (Abirami et al., 2014). Skin care and treatment are very important in order to make the skin healthy and free from any diseases (Allen and Tracy, 1995).

In a normal condition, skin produces elastase and collagenase enzymes. Moreover, the increased levels of ROS will accelerate the production of both enzymes, and it will hasten the degradation of elastin and collagen which is in the extracellular matrix of the dermis.

*Corresponding author : Endang Lukitaningsih

Email : lukitaningsih_end@ugm.ac.id
On the other hand, the UV exposure will also trigger skin pigmentation since the production of melanin by tyrosinase enzyme is increased (Apak et al., 2007; Apraj and Pandita, 2016). The inhibitor of tyrosinase enzyme such as hydroquinone, kojic acid and azelaic acid are used against skin pigmentation disorders (Aumeeruddy-Elalfi et al., 2016).

Today, there has been many researchers reported that natural resources such as fruits and vegetables containing polyphenol can be as a potential antioxidant. Other important substances derived from our diet, included vitamin A, C, E can also act as antioxidant (Khrisnamurthy and Wadhwani, 2012; Pullar et al., 2017; Lephart, 2018). All of these compounds are beneficial to reduce the risk of skin ageing, because of antioxidant and anti-inflammatory activity on the skin (Bae et al., 2009; Azzini et al., 2010; Ben Ahmed et al., 2016). Strawberry already known containing many bioactive, such as vitamin $C, \beta$ carotene, quercetin, anthocyanin, vitamin $\mathrm{E}$ and polyphenols (phenols, flavonoids, phenolic acids, 
Human Neutrophil Elastase Inhibitory Activity (\%)

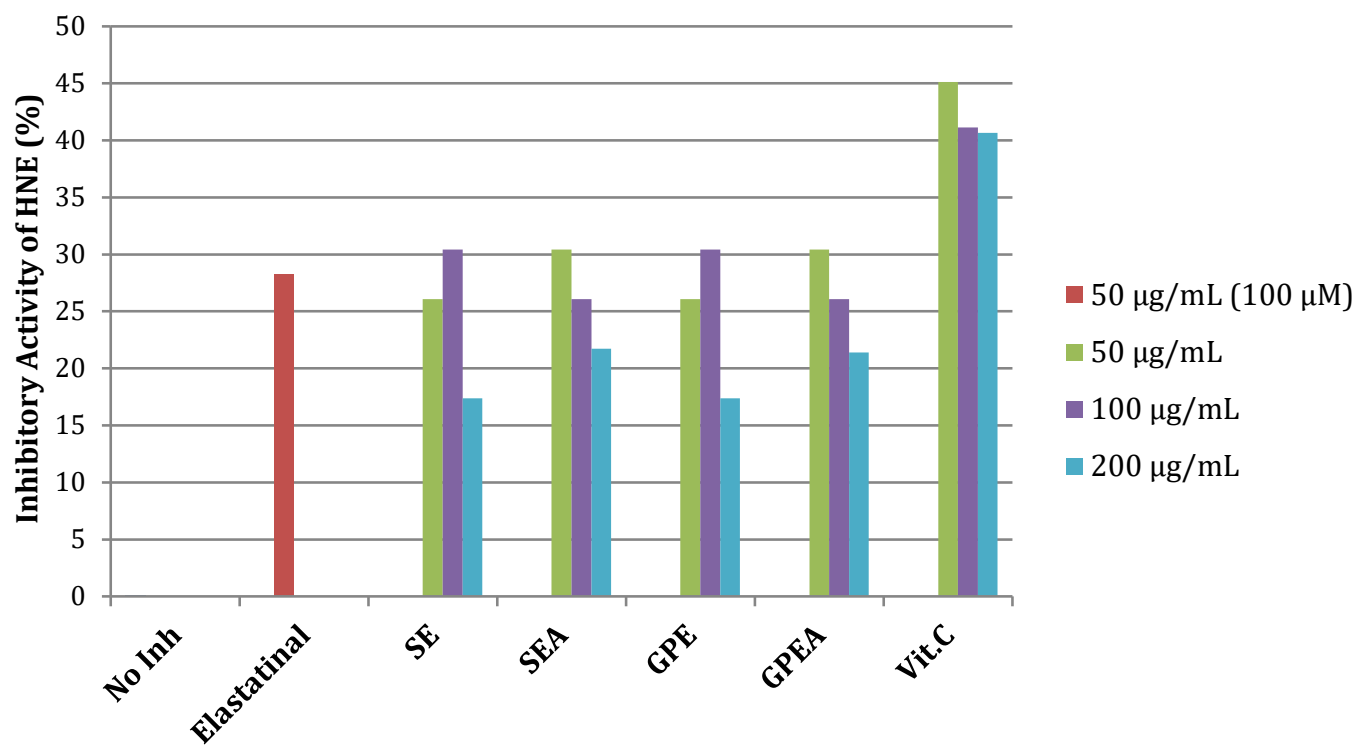

Figure 1. HNE inhibitory activity of extracts, vitamin C (as positive standard) and elastatinal at three different concentrations $(n=3)$

ligands and tannins) (Chang et al., 2013; Ben Ahmed et al., 2016). Citrus Maxima L or grapefruit which is known as Papanus, and is spread widely throughout India. The wooden peel and root of $C$. maxima L. contains $\beta$-sitosterol and acridine alkaloids. Essential oils from leaves and raw fruits contain limonene, neroli, neroli acetate and geraniol. These plants have been commonly used for medical treatment such as sedatives for anxiety, convulsive cough, treatment of haemorrhagic diseases and epilepsy. C. maxima L. also contains a high compound of polyphenol; hesperidin and naringin which show various pharmacological activities that have been previously studied (Cuvelier et al., 1992), which is as an inhibitor of tyrosinase, acetylcholinesterase and $\beta$ glucuronidase enzymes (Karim et al., 2014). Another research claimed that grapefruit ( $C$. maxima L.) can be used as skin moisturizer and is made in cream form. Additionally, vitamin A and C in grapefruit are also able to fight free radical well (Xu et al., 2008).

\section{METHODOLOGY \\ Materials}

The sample of grapefruit (C. Maxima L.) was obtained from Bantul Residence, Yogyakarta, Indonesia. The ripped strawberry sample was obtained from strawberry farm in Bandung, West Java, Indonesia.
Chemicals used in this research include: Ethanol (JT-Baker, USA), ethyl acetate (JT-Baker, USA), dimethyl sulfoxide (DMSO), 10\% SDS, HCl, 28 N-succinyl- (ala) 3-p-nitroanilide (Sigma, USA) and buffers Tris-Cl (Sigma, USA), tyrosinase (mushroom) enzyme (sigma, USA), enzyme Neutrophil Human Elastase (Enzo Life Science, USA), elastatinal inhibitor (Enzo Life Science, USA), MeOSuc-AAPV-pNa substrate, enzyme Matrix Metalloproteinase-1 (MMP-1, Enzo Life Science, USA)), MMP-substrate (BML-P125-9090) (Enzo Life Science, USA), NNGH inhibitors (Enzo Life Science, USA), kojic acid, ascorbic acid (Merck, Germany), L-Dopa, iron (II) sulphate (FeSO4. 7H2O) (sigma, USA), 2,4,6-tripiridyl-s-triazine (TPTZ) (sigma, USA), FeCl3 (sigma, USA), linoleic acid, Tween 20 (sigma, USA), $\beta$-carotene (sigma, USA), butyl hydroxy toluene (BHT) (sigma, USA), sodium acetate.

\section{Instrumentation}

Glassware, laminar air flow cabinet (Labconco, Kansas), centrifuge (Sorvall, USA), UVVis spectrophotometer (Shimadzu, Japan), ELISA Reader (Bio-rad Benchmark, Japan and Corona electric type SH-1000), rotary evaporator (IKA, Germany), micro pipettes (Socorex, Switzerland), analytical balance (Sartorius, Germany), vortex (Shimadzu, Japan), Ovens (Memmert, Germany), incubator (Heraeus, Germany), 96 plate well (pyrex). 
Table I. Persen yield of SE, SEA, GPE and GPEA extracts

\begin{tabular}{clc}
\hline No & \multicolumn{1}{c}{ Extract } & Yield (\%) \\
\hline 1 & Ethanolic Extract of Strawberry (SE) & 1.58 \\
2 & Ethyl Acetate Extract of Strawberry (SEA) & 0.31 \\
3 & Ethanolic Extract of Grapefruit Peel (GPE) & 4.60 \\
4 & Ethyl Acetate Extract of Grapefruit Peel (GPEA) & 3.51 \\
\hline
\end{tabular}

Table II. Phenolic and Flavonoid content in Extract

\begin{tabular}{lcc}
\hline Sample & $\begin{array}{c}\text { Phenolic Content } \\
\text { (\% equivalent to Gallic acid) }\end{array}$ & $\begin{array}{c}\text { Flavonoid Content } \\
\text { (\% equivalent to } \\
\text { Quercetin) }\end{array}$ \\
\hline Ethanolic Extract of Strawberry (SE) & $3.5 \pm 0.04$ & $2.58 \pm 0.01$ \\
Ethyl Acetate Extract of Strawberry (SEA) & $2.12 \pm 0.04$ & $1.38 \pm 0.04$ \\
Ethanolic Extract of Grapefruit Peel (GPE) & $4.22+0.06$ & $11.25+0.06$ \\
Ethyl Acetate Extract of Grapefruit Peel (GPEA) & $2.38+0.07$ & $5.95+0.02$ \\
\hline
\end{tabular}

\section{Sample Preparation and extraction}

The first step was to clean 5 kilograms of fresh strawberries by washing it in flowing water, and then blended them using blender. The blended sample was then extracted using $96 \%$ of ethanol and ethyl acetate by maceration method. Every 100 grams of the sample was extracted by $300 \mathrm{~mL}$ of the ethanol and then stand it be for $1 \times 24$ hours. Next, the sample was then filtered and the residue was macerated again using $96 \%$ of ethanol. The following step was to macerate the residue again by ethyl acetate using the same method. Each extracted result from the maceration was then evaporated using rotary evaporator until it got the strawberry extract of ethanolic and ethyl acetate (SE and SEA) which was ready to test the activity.

For the grapefruit, the first step was to wash the $5 \mathrm{~kg}$ of grapefruit by washing it in flowing water. After that, the sample was peeled and peels were dried using an oven at $50^{\circ} \mathrm{C}$ until it became dried. The dried sample was then weighed and macerated for 1x24 hours using 96\% of ethanol solvent as much as $5 \mathrm{~L}$ for each $1 \mathrm{~kg}$ of sample. The maceration and residue were separated using filter, then the residue was macerated again by $96 \%$ ethanol with the same method in three times repetition. Then the residue was macerated again by ethyl acetate solvent for $1 \times 24$ hours and then was filtered. Residue was macerated again by ethyl acetate solvent with the same method in three times repetition. The ethanol and ethyl acetate maceration were evaporated using a rotary evaporator until it got concentrated extract of grapefruit peel in ethanol and ethyl acetate (GPE and GPEA, respectively) which was ready to be tested. The extract yield was then measured using the below formula:

$$
\text { Yield } \%=\frac{\text { the weight of extract obtained }}{\text { the weight of sample }} \times 100 \%
$$

\section{Determination of phenolic and flavonoid content}

Determination of flavonoid content was conducted by the aluminium chloride colorimetric method (Chang et al., 2002; Ahmad et al., 2015; Baba and Malik, 2015; Klungsupya et al., 2015). Briefly, $50 \mu \mathrm{L}$ of extract was made up to $1 \mathrm{~mL}$ with methanol, then mixed with $4 \mathrm{~mL}$ of distilled water and incubated for $5 \mathrm{~min}$. After that followed by adding $0.3 \mathrm{~mL}$ of $5 \% \mathrm{NaNO}_{2}$ solution; $0.3 \mathrm{~mL}$ of $10 \% \mathrm{AlCl}_{3}$ solution, and the mixture was allowed to stand for $6 \mathrm{~min}$. Then, $2 \mathrm{~mL}$ of $1 \mathrm{~mol} / \mathrm{L} \mathrm{NaOH}$ solution was added, and the final volume of the mixture was brought to $10 \mathrm{~mL}$ with distilled water. The mixture was allowed again to stand for $15 \mathrm{~min}$, and measured absorbance at $510 \mathrm{~nm}$. The total flavonoid content was calculated from a calibration curve, and the data was expressed as mg quercetin equivalent per $100 \mathrm{~g}$ dry weight.

Determination phenolic content was performed according to Folin - Ciocalteu's method. Briefly, put $0.05 \mathrm{~mL}$ of extract and $0.45 \mathrm{~mL}$ distilled water into flask, and then mixed with $2.5 \mathrm{~mL}$ of 1:10 $2 \mathrm{~N}$ Folin - Ciocalteu's phenolic reagent (Sigma Aldrich). Thereafter $2 \mathrm{~mL}$ of $7.5 \%$ (w/v) sodium carbonate was added and heated at $50{ }^{\circ} \mathrm{C}$ for 5 minutes. After that, absorbance was read at $760 \mathrm{~nm}$ with a UV/vis spectrophotometer (Varion Cary IE) in room temperature. Total phenolic content was estimated according to a Gallic acid 


\section{Collagenase Inhibitory Activity (\%)}

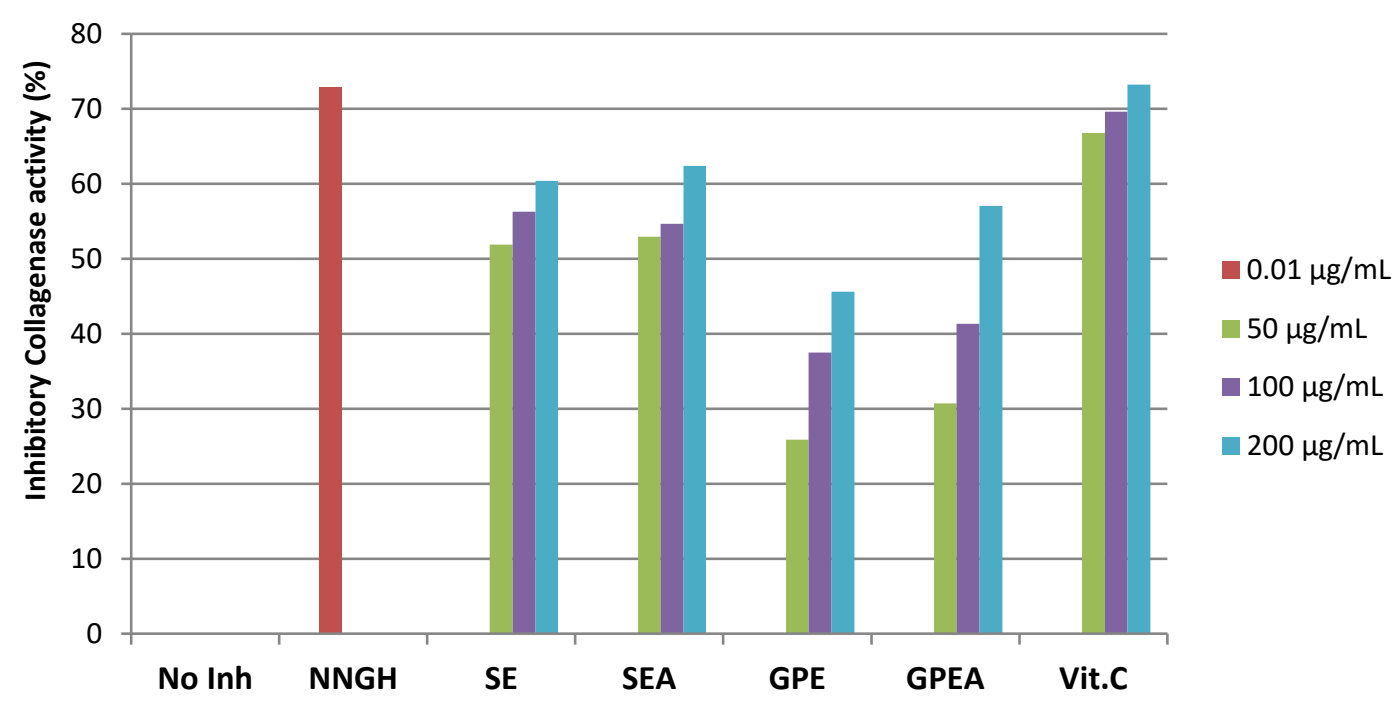

Figure 2. Collagenase inhibitory activity of extracts, vitamin C (as positive standard) and NNGH at three different concentrations $(n=3)$

Table III. Antioxidant of samples determined by using FRAP and BCB method

\begin{tabular}{lcc}
\hline Sample & $\begin{array}{c}\text { IC } 50 \\
\text { (FRAP) }\end{array}$ & $\begin{array}{c}\text { IC }_{\mathbf{5 0}}(\boldsymbol{\mu g} / \mathbf{m L}) \\
\text { (BCB) }\end{array}$ \\
\hline Ethanolic Extract of Strawberry (SE) & $404.39 \pm 3.27$ & $292.30 \pm 4.69$ \\
Ethyl Acetate Extract of Strawberry (SEA) & $1978.65 \pm 3.27$ & $671.11 \pm 6.74$ \\
Ethanolic Extract of Grapefruit Peel (GPE) & $219.47 \pm 71.96$ & $245.19 \pm 162.47$ \\
Ethyl Acetate Extract of Grapefruit Peel (GPEA) & $309.44 \pm 95.76$ & $567.54 \pm 95.31$ \\
Quercetin & $18.97 \pm 4.50$ & $135.56 \pm 6.80$ \\
Vitamin C & $24.47 \pm 1.44$ & \\
Butylated hydroxy Toluene (BHT) & - & $38.68 \pm 5.70$ \\
\hline
\end{tabular}

Table IV. The determined result of anti-tyrosinase activity from the sample

\begin{tabular}{lc}
\hline Sample & IC $_{\mathbf{5 0}}$ Anti tyrosinase $(\boldsymbol{\mu g} / \mathbf{m L})$ \\
\hline Ethanolic Extract of Strawberry (SE) & $492.68 \pm 1.43$ \\
Ethyl Acetate Extract of Strawberry (SEA) & $2658.00 \pm 48.08$ \\
Ethanolic Extract of Grapefruit Peel (GPE) & $3312.5 \pm 222.74$ \\
Ethyl Acetate Extract of Grapefruit Peel (GPEA) & $2985 \pm 122.80$ \\
Kojic acid & $111.52 \pm 0.42$ \\
\hline
\end{tabular}

standard curve $(20-100 \mathrm{mg} / \mathrm{mL})$, results were expressed as milligrams of Gallic acid equivalent (GAE) per $100 \mathrm{~g}$ of dry weight (Chang et al., 2002; Ahmad et al., 2015; Klungsupya et al., 2015).

\section{Antioxidant activity test using FRAP}

The Ferric Reducing Antioxidant Power (FRAP) test was conducted according to method (Apak et al., 2007) with a slight modification. Firstly, prepare ferric chloride solution $(3 \mathrm{mM}$ in $5 \mathrm{mM}$ citric acid) and TPTZ solution $(2,4,6-$ tripyridyl-s-triazine; $1 \mathrm{mM}$ in $0.05 \mathrm{M} \mathrm{HCl}$ ). The comparison of quercetin and vitamin $\mathrm{C}$ were made with several series of concentrations which are $7.81 \mu \mathrm{g} / \mathrm{ml} ; 15.63 \mu \mathrm{g} / \mathrm{ml} ; 31.25 \mu \mathrm{g} / \mathrm{ml} ; 62.50$ $\mu \mathrm{g} / \mathrm{ml}$ and $125 \mu \mathrm{g} / \mathrm{ml}$. Then, the samples (SE, SEA, GPE and GPEA) were prepared into each concentration of $5 \mu \mathrm{g} / \mathrm{ml}, 25 \mu \mathrm{g} / \mathrm{ml}, 125 \mu \mathrm{g} / \mathrm{ml}$, $250 \mu \mathrm{g} / \mathrm{ml}, 500 \mu \mathrm{g} / \mathrm{ml}$ and $1000 \mu \mathrm{g} / \mathrm{ml} \mathrm{FeSO}_{4}$ was used to obtain the standard curve and it was made by the concentration of $2.5 \mu \mathrm{g} / \mathrm{ml} ; 5 \mu \mathrm{g} / \mathrm{ml} ; 10$ $\mu \mathrm{g} / \mathrm{ml} ; 20 \mu \mathrm{g} / \mathrm{ml}$ and $40 \mu \mathrm{g} / \mathrm{ml}$. Using pipette, 
it was obtained $30 \mu \mathrm{l}$ of each sample and standard, after that it was put into 96 well plate and then added with $140 \mu \mathrm{l}$ TPTZ solution. Each of the samples was added with $30 \mu \mathrm{FeCl}_{3}$ and measured the absorbance at a wavelength of $620 \mathrm{~nm}$. The sample absorbance data was calculated against the $\mathrm{FeSO}_{4}$ solvent series and its antioxidant capacity was determined as equivalent to $\mu \mathrm{M} \mathrm{Fe}^{3+}$ which was reduced to $\mu \mathrm{M} \mathrm{Fe}^{2+}$.

\section{Antioxidants Activity Test Using BCB}

The $\beta$-carotene bleaching (BCB) test was conducted in accordance to method (Apak et al., 2007) with a slight modification. Beta-carotene solution was made by dissolving $2.0 \mathrm{mg}$ of betacarotene powder in $0.2 \mathrm{ml}$ of chloroform, $0.2 \mathrm{ml}$ of linoleic acid, $2 \mathrm{ml}$ of tween 20 and distilled water to a volume of $100.0 \mathrm{ml}$, and then it was shaken until it became a clear solution. Butyl hydroxyl toluene (BHT) and quercetin were used as a standard and then made as concentration series. For quercetin, the concentration series were 7.81 $\mu \mathrm{g} / \mathrm{ml} ; 15.63 \mu \mathrm{g} / \mathrm{ml} ; 31.25 \mu \mathrm{g} / \mathrm{ml} ; 62.50 \mu \mathrm{g} / \mathrm{ml}$; $125 \mu \mathrm{g} / \mathrm{ml}$ and $250 \mu \mathrm{g} / \mathrm{ml}$. For the standard of BHT, the used concentration series were $3.9 \mu \mathrm{g} / \mathrm{ml} ; 7.8$ $\mu \mathrm{g} / \mathrm{ml} ; 15.6 \mu \mathrm{g} / \mathrm{ml} ; 31.3 \mu \mathrm{g} / \mathrm{ml}$ and $62.5 \mu \mathrm{g} / \mathrm{ml}$. Furthermore, the samples were made in the concentration series of $50 \mu \mathrm{g} / \mathrm{ml}, 250 \mu \mathrm{g} / \mathrm{ml}, 500$ $\mu \mathrm{g} / \mathrm{ml}, 750 \mu \mathrm{g} / \mathrm{ml}$ and $1000 \mu \mathrm{g} / \mathrm{ml}$. From each sample and standard $20 \mu \mathrm{l}$ were piped into 96 plate wells and then it was added with $180 \mu \mathrm{l}$ BCB solution. It was then incubated for 30 minutes at $50^{\circ} \mathrm{C}$ and the absorbance was observed at a wavelength of $450 \mathrm{~nm}$ in the 0th minute until the 120th minute with a 30-minute interval. The antioxidant activity was calculated based on the activity of different degradation of the test sample with degradation to the control (only betacarotene). The rate of degradation of the sample was calculated with the formula:

The rate of the sample degradation $=\ln (\mathrm{a} / \mathrm{b}) \times 1 / \mathrm{t}$

Which: $\ln$ = natural log; $\mathrm{a}=$ Absorbance at 0 minute; $\mathrm{b}=$ Absorbance at 120-minute; $\mathrm{t}=$ time (minute).

Antioxidant activity (AA), described as inhibition relative to the control, is formulated as follow:

$$
\mathrm{AA} \%=\frac{\text { degradation of control }- \text { degradation of sample }}{\text { degradation of control }} \times 100 \%
$$

\section{Anti-tyrosinase Activity Test}

The test of inhibition activity of tyrosinase enzyme was conducted by the spectrophotometry method (Chang et al., 2013; Lukitaningsih and
Holzgrabe, 2014) using L-DOPA as substrate and kojic acid for the positive control. From each sample, the series of concentration was made from $50-1000 \mu \mathrm{g} / \mathrm{mL}$, and $30 \mu \mathrm{L}$ of each of the sample was obtained and added with $125 \mu \mathrm{L}$ of phosphate buffer $(0.1 \mathrm{M}, \mathrm{pH} 6.8)$ and $5 \mu \mathrm{L}$ of tyrosinase enzyme (2500 units $/ \mathrm{mL}$ ). It was incubated for 30 minutes at $37^{\circ} \mathrm{C}$ and added with $40 \mu \mathrm{L}$ of L-DOPA (2.5 $\mathrm{mM}$ ). The absorbance was observed at the wavelength of $515 \mathrm{~nm}$. The measurement was also conducted for the blank solvent and positive control of kojic acid by using the same equation. The percentage of the inhibition was formulated using the formula:

$\%$ inhibition $=\frac{\text { Absorbance of negative control-Absorbance of sample }}{\text { Absorbance of negative control }} x$ $100 \%$

By the linier regression equation of $y=a+$ $\mathrm{bx}$, by which the $\mathrm{x}$ is the sample concentration and the $\mathrm{y}$ is the $\%$ of inhibition, the value of $\mathrm{IC}_{50}$ can be measured by as follow:

$\mathrm{IC}_{50}=\frac{50-a}{b}$

\section{Anti-elastase Activity Test}

The anti-elastase test was carried out based on the manual products of Drug Discovery kit Neutrophil Elastase Coulometric (Ya Luo et al., 2011). The first was to prepare buffer solution containing $10 \mathrm{mM}$ HEPES, $50 \mathrm{mM} \mathrm{NaCl}$ and 0,05\% Tween 20 in DMSO. The sample solution (50-200 $\mu \mathrm{g} / \mathrm{mL}$ ) was piped $20 \mu \mathrm{L}$ using pipette and added with $65 \mu \mathrm{L}$ buffer solvent into 96 well plate. The elastatinal $(100 \mu \mathrm{M})$ was used as an inhibitor control, the $95 \mu \mathrm{L}$ buffer solution as the blank and $85 \mu \mathrm{L}$ buffer solvent as a negative control. The 10 $\mu \mathrm{L}$ of Neutrophil elastase enzyme $(2,2 \mu \mathrm{U} / \mu \mathrm{L})$ was added into the sample, negative control and inhibitor control (the enzyme was not added into the blank) solution. The mixture was incubated for 30 minutes at $37^{\circ} \mathrm{C}$, it was then added with $5 \mu \mathrm{L}$ of substrate (MeOSuc-Ala-Ala-Pro-Val-pNA, $100 \mu \mathrm{M}$ ) into each well and the absorbance was measured at the wavelength of $405 \mathrm{~nm}$ which was observed for 10 minutes at every 1-minute interval. The obtained absorbance data (OD) was then plotted into graphic of observation time (minutes) against the absorbance (OD/minute) to acquire the linier regression equation. The percentage of the enzyme activity inhibition was obtained from inhibitor (sample) slope (v) against the control slope (v) by the formula:

$\%$ inhibition of enzyme activity $=100 \%$ $\left(\frac{V \text { inhibitor }}{V \text { control }} \times 100 \%\right)$ 


\section{Anti-collagenase Test}

The anti-collagenase test was conducted according to manual product method from MMP-1 Colorimetric Drug Discovery Kit. The first ingredient was buffer solution containing $50 \mathrm{mM}$ HEPES, $10 \mathrm{mM} \mathrm{CaCl} 2,0,05 \%$ Brij-35 and $1 \mathrm{mM}$ DTNB in DMSO. The $20 \mu \mathrm{L}$ of sample solution $(5-1000 \mu \mathrm{g} / \mathrm{mL})$ was piped and added with $50 \mu \mathrm{L}$ of buffer solution into 96 well plate. NNGH inhibitor control (N-Isobutyl-N-(4methoxyphenylsulfonyl) glycylhydroxamic acid; $1,3 \mu \mathrm{M}$ ) was used as comparator, $90 \mu \mathrm{L}$ of buffer solvent as the blank and $70 \mu \mathrm{L}$ of buffer solution as negative control. Then $20 \mu \mathrm{L}$ MMP-1 enzyme (153 $\mathrm{mU} / \mu \mathrm{L}$ ) was added into the well containing the sample, inhibitor and negative control (The enzyme was not added into the blank). The mixture was incubated for 30 minutes at $37^{\circ} \mathrm{C}$, then each well was added with $10 \mu \mathrm{L}$ of substrate (thiopeptide, Ac- PLG- [2- mercapto- 4methylpentanoyl]- LG-OC2H5; $100 \mu \mathrm{M}$ ) and the absorbance was measured at the wavelength of $410 \mathrm{~nm}$. The observation was conducted for 10 minutes at every 1-minute interval. The obtained absorbance data (OD) was then plotted into graphic of observation time (minutes) against the absorbance (OD/minute) to acquire the linier regression equation. The percentage of the enzyme activity inhibition was obtained from inhibitor (sample) slope (v) against the control slope (v) by the formula:

$\%$ inhibition of enzyme activity $=100 \%$ $\left(\frac{V \text { inhibitor }}{V \text { control }} \times 100 \%\right)$

\section{CONCLUSION}

The extract of strawberry flesh and grapefruit peel contains antioxidant activity and inhibition of tyrosinase, elastase and collagenase enzymes. The expression of enzyme inhibition could not be compared precisely against the positive control, considering that the expression could not be delivered in the units of $\mathrm{mol} / \mathrm{mL}$. The strawberry flesh extract has more antioxidant, anti-tyrosinase and anti-collagenase compared to the grapefruit peel extract. On the other hand, the extract of GPEA is potentially able to get developed as anti-aging cosmetics ingredients by elastase enzyme inhibition mechanism.

\section{REFERENCES}

Abirami, A., Nagarani, G. and Siddhuraju, P. (2014) 'potential of fresh juice from Citrus hystrix and C . maxima fruits', Food Science and Human Wellness. Beijing Academy of Food Sciences., 3(1), pp. 16-25.
Ahmad, A. et al., (2015) 'Quantification of total phenol, flavonoid content and pharmacognostical evaluation including HPTLC fingerprinting for the standardization of Piper nigrum Linn fruits', Asian Pac. J. Trop. Biomed. Hainan Medical University, 5(2), pp. 101-107.

Ben Ahmed, Z. et al., (2016) 'Determination of optimal extraction conditions for phenolic compounds from: Pistacia atlantica leaves using the response surface methodology', Analytical Methods, 8(31), pp. 6107-6114.

Allen, D. and Tracy, P. (1995) 'No Title', Journal oh Biological Chemistry, 270(3), pp. 14081415.

Apak, R. et al., (2007) 'Comparative evaluation of various total antioxidant capacity assays applied to phenolic compounds with the CUPRAC assay', Molecules, pp. 1496-1547.

Apraj, V. D. and Pandita, N. S. (2016) 'Evaluation of skin anti-aging potential of Citrus reticulata blanco peel', Pharmacognosy Research, 8(3), pp. $160-168$.

Aumeeruddy-Elalfi, Z., Gurib-Fakim, A. and Mahomoodally, M. F. (2016) 'Kinetic studies of tyrosinase inhibitory activity of 19 essential oils extracted from endemic and exotic medicinal plants', South African Journal of Botany, 103, pp. 89-94.

Azzini, E. et al., (2010) 'Bioavailability of strawberry antioxidants in human subjects', British Journal of Nutrition, 104(8), pp. 1165-1173.

Baba, S. A. and Malik, S. A. (2015) 'Determination of total phenolic and flavonoid content, antimicrobial and antioxidant activity of a root extract of Arisaema jacquemontii Blume', Integrative Medicine Research. Taibah University, 9(4), pp. 449-454.

Badriyah and Hastuti, U. S. (2017) 'The effect of pomelo citrus (Citrus maxima var. Nambangan), Vitamin $\mathrm{C}$ and lycopene towards the number reduction of mice (Mus musculus) apoptotic hepatocyte caused of ochratoxin A', AIP Conference Proceedings, 1854(2017).

Bae, J. Y. et al., (2009) 'Bog blueberry anthocyanins alleviate photoaging in ultraviolet-B irradiation-induced human dermal fibroblasts', Molecular Nutrition and Food Research, 53(6), pp. 726-738.

Chang, C. et al., (2002) 'Estimation of Total Flavonoid Content in Propolis by Two Complementary Colorimetric Methods', 10(3), pp. 178-182.

Chang, C. T. et al., (2013) 'Chemical composition and tyrosinase inhibitory activity of 
Cinnamomum cassia essential oil', Botanical Studies, 54(1), pp. 2-8.

Cuvelier, M. E., Richard, H. and Berset, C. (1992) 'Comparison of the Antioxidative Activity of Some Acid-phenols: Structure-Activity Relationship', Bioscience, Biotechnology and Biochemistry, 56(2), pp. 324-325.

Giampieri, F. et al., (2014) 'Polyphenol-rich strawberry extract protects human dermal fibroblasts against hydrogen peroxide oxidative damage and improves mitochondrial functionality', Molecules, 19(6), pp. 7798-7816.

Inomata, S. et al., (2003) 'Possible involvement of gelatinases in basement membrane damage and wrinkle formation in chronically ultraviolet B-exposed hairless mouse', Journal of Investigative Dermatology. Elsevier Masson SAS, 120(1), pp. 128-134.

Karim, A. A. et al., (2014) 'Phenolic composition, antioxidant, anti-wrinkles and Tyrosinase Inhibitory Activities of Cocoa Pod Extract', BMC Complementary and Alternative Medicine, 14(381), pp. 1-13.

Khrisnamurthy, P. and Wadhwani, A. (2012) 'Antioxidant Enzymes and Human Health', in Antioxidant Enzymes and Human Health, pp. 1-18.

Kim, J. H. et al., (2009) 'Compounds with elastase inhibition and free radical scavenging activities from Callistemon lanceolatus', Journal of Medicinal Plants Research, 3(11), pp. 914-920.

Klungsupya, P. et al., (2015) 'Determination of free radical scavenging, antioxidative DNA damage activities and phytochemical components of active fractions from lansium domesticum corr. Fruit', Nutrients, 7(8), pp. 6852-6873.

Lephart, E. D. (2018) 'Equol's anti-aging effects protect against environmental assaults by increasing skin antioxidant defense and ECM proteins while decreasing oxidative stress and inflammation', Cosmetics, 5(1), pp. 1-17.

Lukitaningsih, E. (2014) 'Bioactive Compounds in Bengkoang (Pachyrhizus Erosus) as Antioxidant and Tyrosinase Inhibiting Agents', Indonesian Journal of Pharmacy, 25(2), p. 68.

Menaa, F., Menaa, A. and Tréton, J. (2013) 'Polyphenols against Skin Aging', in Polyphenols in Human Health and Disease, pp. 819-830. doi: 10.1016/B978-0-12398456-2.00063-3.
Nur, S., Rumiyati, R. and Lukitaningsih, E. (2017) 'Screening of Antioxidants, Anti-Aging and Tyrosinase Inhibitory Activities of Ethanolic and Ethyl Acetate Extracts of Fruit Flesh and Fruit Peel Langsat (Lansium domesticum Corr) In Vitro', Majalah Obat Tradisional, 22(1), p. 63.

Nurrochmad, A. et al., (2018) 'Effects of antioxidant, anti-collagenase, anti-elastase, anti-tyrosinase of the extract and fraction from Turbinaria decurrens Bory', Indonesian Journal of Pharmacy, 29(4), pp. 188-199.

Ochiai, A. et al., (2016). 'Rice bran protein as a potent source of antimelanogenic peptides with tyrosinase inhibitory activity', Journal of Natural Products, 79(10), pp. 2545-2551.

Poljšak, B., Dahmane, R. G. and Godić, A. (2012) 'Intrinsic skin aging: The role of oxidative stress', Acta Dermatovenerologica Alpina, Pannonica et Adriatica, pp. 33-36.

Pullar, J. M., Carr, A. C. and Vissers, M. C. M. (2017) 'The Roles of Vitamin C in Skin Health', (Figure 1)

Qonita, F. (2017). Pemanfaatan Ekstrak Buah Strawberry (Fragaria X Ananassa (Duchesne Ex Weston)) Sebagai Bahan Kosmetik: Uji Aktivitas Antiaging dan Antibakteri Secara In Vitro. Yogyakarta: Faculty of Pharmacy, Gadjah Mada University.

Vijaylakshmi, P. and Radha, R. (2015) 'An overview: Citrus maxima', The Journal of Phytopharmacology, 4(5), pp. 263-267. Available at: www.phytopharmajournal .com.

Wang, F. et al., (2008) 'Effect of increased pigmentation on the antifibrotic response of human skin to UV-A1 phototherapy', Archives of Dermatology, 144(7), pp. 851858.

Wong, S. K., Lim, Y. Y. and Chan, E. W. C. (2010) 'Evaluation of antioxidant, anti-tyrosinase and antibacterrial activities of selected Hibiscus species', Ethobotanical Leaflets, 14(June), pp. 781-796.

$\mathrm{Xu}, \mathrm{G}$. et al., (2008) 'Juice components and antioxidant capacity of citrus varieties cultivated in China', Food Chemistry, 106(2), pp. 545-551.

Ya Luo, Hao-ru Tang *, Xiao-rong Wang, Yong Zhang, Z. L. (2011) 'Antioxidant properties and involved antioxidant compounds of strawberry fruit at different maturity stages', Journal of Food, Agriculture and Environment, 9(1), pp. 166-170. 
In Vitro Anti-Wrinkle and Tyrosinase Inhibitory Activities of

Zulbayu, L. ode (no date) Uji Aktivitas Antiaging dan Antibakteri Ekstrak Etanol dan Etil Asetat Kulit Buah Jeruk Bali (Citrus maxima
L.) secara In Vitro. Yogyakarta: Faculty of Pharmacy, Gadjah Mada University. 